\title{
Red cell ferritin content: a re-evaluation of indices for iron deficiency in the anaemia of rheumatoid arthritis
}

\author{
ANNE DAVIDSON, MARTIN B VAN DER WEYDEN, HUBERT FONG， MARGOT J BREIDAHL, \\ PETER F J RYAN
}

\begin{abstract}
In iron deficiency anaemia basic red cell content of ferritin is appreciably reduced. This variable was determined in 62 patients with rheumatoid arthritis to evaluate conventional laboratory indices for iron deficiency in the anaemia of rheumatoid arthritis.

For 23 patients with rheumatoid arthritis and normocytic anaemia irrespective of plasma ferritin concentration, red cell ferritin content did not differ significantly from that for non-anaemic patients with rheumatoid arthritis. For 27 patients with rheumatoid arthritis and microcytic anaemia, the mean red cell ferritin content for patients with a plasma ferritin concentration in the 13-110 $\mu \mathrm{g} / 1$ range was appreciably reduced. It was indistinguishable from that for patients with rheumatoid arthritis and classical iron deficiency anaemia, indicated by plasma ferritin concentrations of less than $12 \mu \mathrm{g} / 1$. In contrast, the mean red cell ferritin content for patients with rheumatoid arthritis, microcytic anaemia, and plasma ferritin concentrations above $110 \mu \mathrm{g} / \mathbf{1} \mathrm{did}$ not differ from that for patients with rheumatoid arthritis and normocytic anaemia. Oral treatment with iron in patients with rheumatoid arthritis, microcytic anaemia, and appreciably reduced red cell ferritin concentrations was accompanied by significant increases in haemoglobin concentration $(p<0.01)$, mean corpuscular volume $(p<0.01)$, and red cell ferritin contents $(p<0.05)$. This treatment, however, did not produce any appreciable change in haemoglobin concentration in patients with rheumatoid arthritis, normocytic anaemia, and normal red cell ferritin contents.

These findings suggest that the indices for iron deficiency in patients with rheumatoid arthritis and anaemia should include peripheral blood microcytosis together with a plasma ferritin concentration of less than $110 \mu \mathbf{g} / \mathbf{1}$.
\end{abstract}

\section{Introduction}

Araemia is common in patients with rheumatoid arthritis, and its severity generally parallels the activity of the disease. ${ }^{1}$ This inflammatory activity also promotes changes in iron metabolism that result in low plasma iron concentrations, reduced transferrin saturation, and microcytic, hypochromic red cells. ${ }^{2}$ In anaemic patients with rheumatoid arthritis these findings are equally consistent with the anaemia of chronic inflammation and

Alfred Hospital, Prahran, 3181 Victoria, Australia

ANNE DAVIDSON, MB, BS, fellow

PETER F J RYAN, MB, FRACP, inead of rheumatology unit

MARTIN B VAN DER WEYDEN, MD, FRACP, clinical associate professor, department of medicine, Monash University Medical School

HUBERT FONG, MSC, scientific officer

MARGOT J BREIDAHL, PHD, FRCPA, director, department of clinical biochemistry

Correspondence to: Dr M B Van Der Weyden. that of iron deficiency. ${ }^{2}$ The concentration of ferritin in plasma is useful in resolving this clinical dilemma, with values of less than $12 \mu \mathrm{g} / 1$ being diagnostic of iron deficiency. ${ }^{34}$ As plasma ferritin is an inflammatory acute phase reactant its clinical value as an indicator for iron deficiency is limited in anaemic patients with rheumatoid arthritis and plasma ferritin concentrations above $12 \mu \mathrm{g} / 1 .^{56}$ In these patients a variable and wide ranging lower limit of plasma ferritin concentration has been arbitrarily set at 55-110 $\mu \mathrm{g} / 1 .{ }^{4}{ }^{6} 7$ This indefinite limit makes the decision of whether to give iron to these anaemic patients difficult. Such uncertainties are relevant as indiscriminate treatment with iron should be avoided; iron may possibly augment the rheumatoid synovial inflammatory process, ${ }^{8}$ and there is also a potential risk of penicillamine nephropathy due to variable absorption from iron penicillamine complex formation. ${ }^{9}$

Human peripheral blood cells contain measurable amounts of ferritin, and basic red cell content of ferritin reflects the state of body iron stores, being raised in pathological iron overload and considerably reduced in uncomplicated iron deficiency anaemia. ${ }^{10-12}$ In the present study we measured laboratory variables, including basic red cell ferritin content, in a large unselected group of anaemic patients with rheumatoid arthritis to define those indices that discriminate true iron deficiency anaemia from the anaemia of chronic inflammation.

\section{Patients and methods}

Twelve men and 50 women, aged 16 to 83 years, with classical or definite rheumatoid arthritis, were available for study. They comprised 11 men and 39 women with anaemia as defined by the criteria of the World Health Organisation (haemoglobin concentration for men $<13.0 \mathrm{~g} / \mathrm{dl}$, for women $<12.0 \mathrm{~g} / \mathrm{dl}$ ) and one man and 11 women, with active rheumatoid arthritis but without anaemia, who were selected as controls. Of these patients, 20 were receiving penicillamine alone and the 42 others were receiving a combination of non-steroidal antiinflammatory agents and either hydroxychloroquine, ${ }^{3}$ intramuscular gold salts, ${ }^{10}$ oral glucocorticoids, ${ }^{9}$ or immunosuppressive agents. ${ }^{13}$ No patient had received oral or parenteral treatment with iron in the preceding six months.

On entry into the study patients were assessed according to standard haematologic variables together with plasma iron, transferrin, and ferritin concentrations and red cell ferritin content. Disease activity was arbitrarily assessed by means of joint counts, duration of morning stiffness, global assessment by a single examiner, and determination of erythrocyte sedimentation rate (westergren).

Anaemia was microcytic (mean corpuscular volume $<80 \mathrm{f}$ ) in 27 of the 50 anaemic patients and normocytic (mean corpuscular volume $80-95 \mathrm{fl}$ ) in 23 . For analysis these patients were arbitrarily divided into four groups according to whether their plasma ferritin concentration was $12 \mu \mathrm{g} / 1$ or less (group 1), 13-55 $\mu \mathrm{g} / 1$ (group 2), 56-110 $\mu \mathrm{g} / 1$ (group 3), or above $110 \mu \mathrm{g} / 1$ (group 4).

After three months 12 patients with microcytic anaemia and 19 patients with normocytic anaemia were evaluated again according to the described clinical, haematological, and iron variables. During this period seven patients with microcytic anaemia and plasma ferritin concentrations below $55 \mu \mathrm{g} / 1$ (groups 1 and 2) and nine with normocytic anaemia and plasma ferritin concentrations of 55-110 and above $\mu \mathrm{g} / \mathrm{l}$ (groups 2 to 4 ) were given ferrous sulphate $350 \mathrm{mg}$ daily. Three patients taking penicillamine and oral iron separated the iron and penicillamine doses by at least six hours. ${ }^{9}$

- Basic red cell ferritin content and plasma ferritin concentration were assayed, as described in greater detail previously, with the hepatic ${ }^{125}$ ferritin immunoassay (Gammadab Travenol Laboratories Inc, Massa- 
chusetts, USA). ${ }^{14}$ Basic red cell ferritin content was expressed as attogram/cell (one attogram (ag) $=10^{-18} \mathrm{~g}$ ), which for 17 normal men and 15 normal women ranged from 4-47 ag/cell, geometric mean $10.7 \mathrm{ag} /$ cell $^{14}$ To measure other biochemical variables standard techniques were used. ${ }^{15}{ }^{16}$ Peripheral blood haematological indices were determined by automated techniques in an Ortho ELT-800 Laser Analyzer (Ortho Diagnostic System Inc, Massachusetts, USA).

Statistical analysis was done with Student's $t$ test. As with plasma ferritin concentration, red cell ferritin content is log normally distributed, ${ }^{17}$ and for these variables statistical analysis was performed with $\log$ transformed data and results were transformed again as antilogs to recover original units of measurement.

\section{Results}

Of the 62 patients with rheumatoid arthritis whom we evaluated, 12 had normal haemoglobin concentrations. The mean basic red cell ferritin content of $6.5 \mathrm{ag} /$ cell (range 2-30 ag/cell) for this group was
Table I also shows values for 27 patients with rheumatoid arthritis and microcytic anaemia. The haemoglobin and plasma iron concentrations and the degree of transferrin saturation for patients in each group did not differ significantly. The reduced mean corpuscular volume showed a progressive increase from mean 72 (SD 4) $\mathrm{fl}$ for patients with a plasma ferritin concentration below $55 \mu \mathrm{g} / 1$ (groups 1 and 2) to 77 (3) fl for patients with a plasma ferritin concentration greater than $110 \mu \mathrm{g} / 1$ (group 4, $\mathrm{p}<0.05$ ).

The mean red cell ferritin content for all patients with microcytic anaemia was significantly lower than that for a normal population (groups 1 to $3, \mathrm{p}<0.001$; group $4, \mathrm{p}<0.05$ ), but only the patients with microcytic anaemia and a plasma ferritin concentration of less than $110 \mu \mathrm{g} / 1$ (groups 1 to 3 ) had mean red cell ferritin concentrations significantly lower than those for non-anaemic patients with rheumatoid arthritis or patients with rheumatoid arthritis and normocytic anaemia $(\mathrm{p}<0.05)$.

Table II shows the results of three months' treatment with oral iron in seven patients with microcytic anaemia and nine with normocytic anaemia and compares these findings with those from patients who did

TABLE I-Geometric mean (range) ferritin values and mean (SD) haematological variables in anaemic patients with rheumatoid arthritis

\begin{tabular}{|c|c|c|c|c|c|c|c|}
\hline & $\begin{array}{c}\text { No of } \\
\text { patients }\end{array}$ & $\begin{array}{l}\text { Plasma } \\
\text { ferritin } \\
(\mu \mathrm{g} / 1)\end{array}$ & $\begin{array}{l}\text { Haemoglobin } \\
(\mathrm{g} / \mathrm{dl})\end{array}$ & $\begin{array}{l}\text { Mean } \\
\text { corpuscular } \\
\text { volume } \\
(\mathrm{fl})\end{array}$ & $\begin{array}{c}\text { Plasma } \\
\text { iron } \\
(\mu \mathrm{mol} / \mathrm{l})\end{array}$ & $\begin{array}{c}\text { Transferrin } \\
\text { saturation } \\
\left(\begin{array}{c}0 \\
0 \\
0\end{array}\right)\end{array}$ & $\begin{array}{l}\text { Red cell } \\
\text { ferritin } \\
\text { (ag/cell) }\end{array}$ \\
\hline Normal values & & $20-200$ & $\left\{\begin{array}{l}\text { women }>12 \\
\text { men }>13\end{array}\right.$ & $80-95$ & $7-32$ & $18-45$ & $10 \cdot 7(4-47)$ \\
\hline $\begin{array}{l}\text { Group } 2^{+} \\
\text {Group } 3_{+}^{+} \\
\text {Group } 4 \S\end{array}$ & $\begin{array}{r}10 \\
4 \\
9\end{array}$ & $\begin{aligned} & \text { Patients } \\
30 & (16-54) \\
79 & (64-107) \\
223 & (112-989)\end{aligned}$ & $\begin{array}{c}h \text { rheumatoid art } \\
11.2(0.8) \\
10.5(0.8) \\
10.5(0.8)\end{array}$ & $\begin{array}{l}\text { is and normoc } \\
87(6) \\
89(3) \\
87(4)\end{array}$ & $\begin{array}{c}\text { aemia }(n= \\
8(3) \\
9(4) \\
9(4)\end{array}$ & $\begin{array}{l}13(5) \\
17(6) \\
19(10)\end{array}$ & $\begin{array}{l}3 \cdot 6(2-18) \\
4 \cdot 8(4-7) \\
8 \cdot 7(3-23)\end{array}$ \\
\hline \multicolumn{8}{|c|}{ Patients with rheumatoid arthritis and microcytic anaemia $(n=27)$} \\
\hline $\begin{array}{l}\text { Group } 1^{*} \\
\text { Group } 2^{+} \\
\text {Group } 3+ \\
\text { Group } 4 \S\end{array}$ & $\begin{array}{l}8 \\
5 \\
7 \\
7\end{array}$ & $\begin{aligned} 6 & (2 \cdot 5-12) \\
32 & (23-53) \\
86 & (57-110) \\
235 & (123-311)\end{aligned}$ & $\begin{array}{r}10 \cdot 1(1 \cdot 1) \\
9 \cdot 8(1 \cdot 6) \\
10.0(1 \cdot 1) \\
10.7(0.9)\end{array}$ & $\begin{array}{l}72(4) \\
72(4) \\
75(5) \\
77(3)\end{array}$ & $\begin{array}{l}5(3) \\
5(3) \\
7(6) \\
5(2)\end{array}$ & $\begin{array}{c}8(5) \\
8(6) \\
15(10) \\
11(5)\end{array}$ & $\begin{array}{l}1 \cdot 2(0.5-4) \\
1.0(0 \cdot 5-3) \\
1 \cdot 5(0 \cdot 5-3) \\
4 \cdot 4(2-15)\end{array}$ \\
\hline
\end{tabular}

Plasma ferritin concentrations: $* \leqslant 12 \mu \mathrm{g} / 1 ;+13-55 \mu \mathrm{g} / 1 ; \ddagger 56-110 \mu \mathrm{g} / 1 ; \S>110 \mu \mathrm{g} / 1$.

Conversion: SI to traditional units-Iron: $1 \mu \mathrm{mol} 1 \approx 5 \cdot 6 \mu \mathrm{g} / 100 \mathrm{ml}$.

TABLE II-Haematological variables before and after three months' treatment with oral iron in patients with rheumatoid arthritis and anaemia

\begin{tabular}{|c|c|c|c|c|c|c|}
\hline & \multicolumn{4}{|c|}{ Mean (SD) } & \multicolumn{2}{|c|}{ Geometric mean (range) } \\
\hline \multicolumn{7}{|c|}{ Patients with microcytic anaemia } \\
\hline $\begin{array}{l}\text { Patients given oral iron }(n=7) \text { : } \\
\text { Before } \\
\text { After }\end{array}$ & $\begin{array}{r}9.4(1 \cdot 7)^{* * *} \\
12.8(1 \cdot 4)^{* * * *}\end{array}$ & $\begin{array}{l}70(5) * * * * \\
82(5) * * * *\end{array}$ & $\begin{array}{l}4(3) \\
6(3)\end{array}$ & $\begin{array}{l}5(4) \\
6(4)\end{array}$ & $\begin{aligned} 7 & (2.5-24)^{*} \\
33 & (19-92)^{*}\end{aligned}$ & $\begin{array}{l}1.2(0.5-4)^{* *} \\
5.6(0.5-36)^{* *}\end{array}$ \\
\hline \multicolumn{7}{|c|}{ Patients with normocytic anaemia } \\
\hline $\begin{array}{l}\text { Patients given oral iron }(n=9) \text { : } \\
\text { Before } \\
\text { After } \\
\text { Patients not given oral iron }(n=10) \text {. }\end{array}$ & $\begin{array}{l}11 \cdot 0(0 \cdot 7) \\
11 \cdot 5(0.8)\end{array}$ & $\begin{array}{l}88(4) \\
87(4)\end{array}$ & $\begin{array}{l}9(2) \\
9(2)\end{array}$ & $\begin{array}{l}15(3) \\
17(4)\end{array}$ & $\begin{array}{l}50(17-156) \\
92(30-319)\end{array}$ & $\begin{array}{r}6(3-18)^{* *} \\
11(5-24)^{* *}\end{array}$ \\
\hline $\begin{array}{l}\text { Patients not given oral iron }(n=10) \text { : } \\
\text { Before } \\
\text { After }\end{array}$ & $\begin{array}{l}11.3(0.8) \\
11.9(0.9)\end{array}$ & $\begin{array}{l}82(6) \\
89(3)\end{array}$ & $\begin{array}{l}8(3) \\
8(3)\end{array}$ & $\begin{array}{l}15(5) \\
17(9)\end{array}$ & $\begin{array}{l}114(29-487) \\
108(21-463)\end{array}$ & $\begin{array}{l}7(2-23) \\
9(3-41)\end{array}$ \\
\hline
\end{tabular}

not significantly different from that for a normal population $(10 \cdot 7$ (range 4-47 ag/cell)).

Table I shows the variables conventionally measured to assess anaemia together with the red cell ferritin content for 23 patients with rheumatoid arthritis and normocytic anaemia. We did not identify any patients with normocytic anaemia and a plasma ferritin concentration of less than $12 \mu \mathrm{g} / \mathrm{l}$. Findings from investigation of patients, when grouped according to plasma ferritin concentrations, did not show any significant difference for haemoglobin concentration, mean corpuscular volume, or degree of transferrin saturation. The mean red cell ferritin content for each of the three groups of patients with normocytic anaemia was not significantly different from that for the 12 patients with rheumatoid arthritis and a normal haemoglobin concentration. not receive oral iron. There was no significant difference in variables of activity of the disease between the four groups and there was no significant change in these variables between groups before or after treatment with oral iron (data not shown).

\section{Discussion}

Iron deficiency anaemia in patients with rheumatoid arthritis may be difficult to distinguish from the microcytic anaemia found in chronic inflammatory disease. In uncomplicated iron deficiency reduced marrow iron is a reliable index for this 
deficiency. This reduction in stainable marrow iron correlates with both microcytosis and lowered plasma ferritin concentrations. ${ }^{18} 19$ In addition, a plasma ferritin concentration of less than $12 \mu \mathrm{g} / \mathrm{l}$ is a clear indication for treatment with iron in an anaemic patient. ${ }^{5}$ Plasma ferritin concentrations in patients with rheumatoid arthritis show, however, a less satisfactory correlation with bone marrow iron, as normal plasma ferritin concentrations are found with absent bone marrow iron. ${ }^{34}$ Although a plasma ferritin concentration of less than $12 \mu \mathrm{g} / \mathrm{l}$ indicates iron deficiency, the diagnostic importance of concentrations above $12 \mu \mathrm{g} / \mathrm{l}$ is not entirely clear as the lower limit of plasma ferritin concentration for these patients has not been clearly defined. ${ }^{3}{ }^{4}$ Because of these conflicts other potential indices of iron deficiency in patients with rheumatoid arthritis need to be explored; in this study we evaluated basic red cell content of ferritin.

Basic red cell ferritin content reflects the rate of uptake of iron by marrow erythroid cells, which is dependent in part on the degree of transferrin saturation. ${ }^{10-12}$ Thus in iron deficiency and, to a lesser degree, the anaemia of chronic inflammation, both characterised by low plasma iron concentration and reduced transferrin saturation, ${ }^{2}$ basic red cell ferritin content is reduced. 111220

In the present study we determined the basic red cell ferritin content of patients with rheumatoid arthritis and indisputable iron deficiency anaemia as indicated by microcytosis and a plasma ferritin concentration below $12 \mu \mathrm{g} / \mathrm{l}^{3}{ }^{4}$ The red cell ferritin content for this group was then compared with that for anaemic patients with rheumatoid arthritis and either normocytic or microcytic blood changes and variable plasma ferritin concentrations. The basic red cell ferritin content for patients with microcytic anaemia and plasma ferritin concentration in the range 13-110 $\mu \mathrm{g} / 1$ was not significantly different from that for other anaemic patients with rheumatoid arthritis and classical iron deficiency or non-arthritic patients with iron deficiency anaemia. ${ }^{20}$ Patients with microcytic anaemia and plasma ferritin concentrations above $110 \mu \mathrm{g} / \mathrm{l}$ showed appreciably higher values for mean corpuscular volume and a mean red cell ferritin content no different from that for patients with normocytic anaemia. In the patients with normocytic anaemia, the red cell ferritin for patients with plasma ferritin concentration above $110 \mu \mathrm{g} / \mathrm{l}$ was not significantly different from that for a normal population. In patients with this anaemia and a plasma ferritin concentration of $13-110 \mu \mathrm{g} / \mathrm{l}$ red cell ferritin content was significantly reduced compared with that for a normal population but not compared with that for patients with rheumatoid arthritis and normal haemoglobin concentrations.

These findings suggest that in anaemic patients with rheumatoid arthritis a plasma ferritin concentration in the $13-110 \mu \mathrm{g} / \mathrm{l}$ range, in itself, is not predictive for variables associated with iron deficiency anaemia-namely, pronounced microcytosis and a reduced red cell ferritin content. An explanation for this paradox may be that in patients with rheumatoid arthritis iron is redistributed into body compartments that sequester this metal, not altering plasma ferritin concentration but effectively reducing the amount of iron available for erythropoiesis. The degree of this iron compartmentalisation may determine the development of iron deficiency anaemia in patients with rheumatoid arthritis who have similar plasma ferritin concentrations. Sites for this abnormal distribution of body iron include lymph nodes ${ }^{13}$ and synoviums. ${ }^{2122}$ A synovial iron content of $800 \mathrm{mg}$ has been estimated to represent patients who have widespread active disease. ${ }^{23}$

Our findings suggest that the pragmatic clinical indicators for iron deficiency in anaemic patients with rheumatoid arthritis should include microcytosis together with a plasma ferritin concentration of up to $110 \mu \mathrm{g} / \mathrm{l}$. The reduced red cell ferritin content in patients with normocytic anaemia and a plasma ferritin concentration ranging from 13 to $110 \mu \mathrm{g} / \mathrm{l}$ may simply reflect iron metabolic changes consequent on chronic inflammation. Only extensive formal studies evaluating the therapeutic effect of oral iron in these patients will resolve this uncertainty. The response to treatment with oral iron in the limited number of patients with anaemia and rheumatoid arthritis in this study was compatible with the above suggestions. Oral iron treatment did not have any significant effect on the haemoglobin or plasma ferritin concentrations or the red cell ferritin content of patients with normocytic anaemia. In patients with microcytic anaemia and appreciably reduced red cell ferritin concentration, treatment with iron resulted in an appreciable rise in haemoglobin concentration, which was accompanied by increases in red cell and plasma ferritin concentrations, independent of disease activity. These results suggest that more extensive trials are required to evaluate the effect of oral iron treatment in selected patients with rheumatoid arthritis and anaemia grouped according to the findings of this study.

This study was supported in part by a special research grant from Monash University. We thank the staff of the departments of clinical biochemistry and haematology at the Alfred Hospital for help in biochemical and haematological tests; and the physicians at the Alfred Hospital and Prince Henry's Hospital, Melbourne, who referred patients to us.

\section{References}

1 Mowat AG. Haematologic abnormalities in rheumatoid arthritis. Semin Arthritis Rheum 1971;1:195-219.

2 Lee GR. The anemia of chronic disease. Semin Hematol 1983;20:61-80.

Bentley DP, William P. Serum ferritin concentration as an index of storage iron in rheumatoid arthritis. $\mathcal{F}$ Clin Pathol $1974 ; 27: 786-8$

4 Smith RJ, Davis P, Thomson ABR, Wadsworth LD, Fackre P. Serum ferritin levels in the anemia of rheumatoid arthritis. $\mathcal{F}$ Rheumatol 1977;4:389-92.

5 Lipschitz DA, Cook JD, Finch CA. A clinical evaluation of serum ferritin as an index of iron stores. $N$ Engl f Med $1974 ; 290: 1213-6$

作 by assay of serum ferritin concentrations. $\mathrm{Br}$ Med $\mathcal{F} 1981 ; 283: 1142-8$. oesner HP. Iron metabolism in inflammation and malignant disease. In: Jacobs A, Worwood M, eds.

8 Blake DR, Hall ND, Bacon PA, Dieppe PA, Halliwell B, Gutteridge JMC. The importance of iron in rheumatoid arthricis. Lancet 1981 ;ii:1142-3.

9 Harkness JAL, Blake DR. Penicillamine nephropathy and iron. Lancet 1982;ii: 1368-9.

10 Van Der Weyden MB, Fong H, Salem HH, Batey RG, Dudley FJ. Erythrocyte ferritin content in idiopathic haemochromatosis and alcoholic liver disease with iron overload. $\mathrm{Br}$ Med f 1983;286:752-4

11 Peters SW, Jacobs A, Fitzsimmons E. Erythrocyte ferritin in normal subjects and patients with abnormal iron metabolism

12 Cazzola $M$, Dezza L, Bergamaschi G, et al. Biologic and clinical significance of red cell ferritin. Blood 1983;62:1078-87.

3 Muirden KD. Lymph node iron in rheumatoid arthritis. Histology ultrastructure Ann Rheum Dis 1970;29:81-8.

14 Van Der Weyden $M B$, Fong $H$, Hallam $L$, Breidahl MJ. A rapid and simple assay for human erythrocyte ferritin. Clin Chim Acta 1983;127:397-401.

15 Gioraniello TJ, Di Benedetto G, Palmer DN, Peters T Jr. Fully automated method for the determination of serum iron and total iron binding capacity. In: Scova NB, Barabas S, Golin JE, et al, eds. Automation in analytical chemistry. Technicon Symposium, 1967. Vol 1. White Plains, New York: Mediod, 1968 $185-8$.

16 Sternberg JC. A rate nephelometer for measuring specific protein by immuno-

17 Lipschitz DA, Cook JD, Finch CA. Ferritin in formed blood elements. Proc Soc Exp Biol Med 1975;148:358-64.

18 Brink S, Van Schalkwyk DJ. Serum ferritin and mean corpuscular volume as predictors of bone marrow iron stores. $S$ Afr Med $\mathcal{F} 1982 ; 61: 432-4$.

19 Krause JR, Stolc V. Serum ferritin and bone marrow iron stores. Correlation with absence of iron in biopsy specimens. Am f Clin Pathol 1979;72:817-20. patients with anemia and polycythemia vera. Pathology (in press).

Mowat AG, Hothersall TE. Nature of anaemia in rheumatoid arthritis. VIII. Iron content of synovial tissue in patients with rheumatoid arthritis and normal individuals. Ann Rheum Dis 1968;2:345-51.

22 Senator GB, Muirden KD. Concentration of iron in synovial membrane, synovial fluid and serum in rheumatoid arthritis and other joint diseases. Ann Rheum Dis $1968 ; 27: 49-54$.

23 Anonymous. Iron in rheumatoid synovium. Lancet 1968;ii:340-1.

(Accepted 4 fune 1984) 